\title{
Knowledge, risk perception and attitudes of Dentistry students with regard to HIVIAIDS
}

\author{
Conhecimento, percepção de risco e atitudes de acadêmicos de Odontologia sobre HIV/AIDS
}

Verena Carvalho Sampaio de MAGALHÃES'

Danillo Lyrio de OLIVEIRA ${ }^{1}$

Fabio Ornellas PRADO²

\section{ABSTRACT}

\section{Objective}

To assess the knowledge, perception of risk and attitudes of Dentistry students regarding HIVIAIDS.

\section{Methods}

A descriptive, observational, cross-sectional study was performed by applying a questionnaire containing 33 objective questions to students enrolled in the Dentistry course at Southwest Bahia State University, between the second and final years.

\section{Results}

The response rate was $74 \%$, with an average overall score of $64.1 \%$ for the knowledge variable, considered to be good. The average overall score for risk perception was $61.7 \%$ (considered inadequate), borne out by a significant rate of accidents involving sharps (25\%). An average overall score of $54.3 \%$ revealed negative attitudes, showing that some students feel apprehensive and unprepared to treat HIV+ patients.

\section{Conclusion}

In view of the fact that the attitude and risk perception variables studied showed results that fall short of expectations, even with a knowledge variable considered to be good, a greater articulation between theory and practice is suggested.

Indexing terms: HIV infections. Knowledge. Students, Dental.

\section{RESUMO}

\section{Objetivo}

Avaliar o conhecimento, percepção de risco e atitudes dos acadêmicos de um curso de graduação em Odontologia sobre HIVIAIDS.

\section{Métodos}

Foi realizado estudo descritivo observacional transversal, aplicando-se questionário com 33 questões objetivas aos alunos do segundo ao último ano do curso de Odontologia da Universidade Estadual do Sudoeste da Bahia.

\section{Resultados}

A taxa de resposta foi de $74 \%$, com escore médio geral de $64,1 \%$ para a variável conhecimento, sendo considerado bom conhecimento. 0 escore médio geral de percepção de risco foi de 61,7\% (percepção de risco inadequada), confirmado por considerável índice de acidentes com perfurocortantes (25\%). O escore médio geral de $54,3 \%$ revelou atitude negativa, mostrando que alguns acadêmicos se sentem receosos e despreparados para atender um paciente HIV+.

\section{Conclusão}

Tendo em vista que as variáveis estudadas, atitudes e percepção de risco, evidenciaram resultados aquém do esperado, mesmo com um conhecimento considerado bom, sugere-se maior articulação entre teoria e prática.

Termos de indexação: Infecções por HIV. Conhecimento. Estudantes de odontologia;

\section{INTRODUCTION}

Faced with the high number of patients with HIVIAIDS, it has become necessary to adapt the attitudes of health professionals and students to reality ${ }^{1-5}$. From 2012 to mid-2013, 35.3 million people worldwide were reported to be living with AIDS $^{6}, 718,000$ alone in
Brazil. The highest detection rates were found in Brazil's Southern region, with a rate of 30.9 cases per 100,000 people; the lowest rates were found in the Northeastern region, with a rate of 14.8 cases per 100,000 people. However, in the last 10 years, there has been a $2 \%$ increase in Brazil's detection rate, with a $62.6 \%$ increase in the Northeastern region?.

\footnotetext{
${ }^{1}$ Universidade Estadual do Sudoeste da Bahia, Curso de Odontologia. Jequié, BA, Brasil.

${ }^{2}$ Universidade Estadual do Sudoeste da Bahia, Curso de Odontologia, Departamento de Saúde 1. Av. José Moreira Sobrinho, s/n., Jequiezinho, 45206510, Jequié, BA, Brasil. Correspondência para / Correspondence to: FO PRADO.E-mail:<fop_@hotmail.com>.
} 
Controlling infectious diseases is an aspect that deserves close attention in dentistry, due to both the environment in which a dental surgeon works (the oral environment, with its numerous microorganisms) and to the wide range of sharp instruments and invasive procedures, exposing the dentist to various infectious/ contagious diseases, such as AIDS and Hepatitis B and $C$, depending on factors including depth of the cut, the volume of potentially infectious fluid on dental instruments and the patient's viral load during seroconversion ${ }^{8-13}$.

Therefore it is essential to seek and constantly update knowledge on occupational diseases to which the dental professional may be exposed, routes of infection, modes of transmission, bio-security standards, sterilization and disinfection of the materials used, proper disposal of waste, respect for the environment and on post-exposure measures. In this way, a professional will be able to protect him/herself and his/her entire team, as well as the patients themselves ${ }^{14-15}$. Of equal importance is knowledge concerning the main oral manifestations of HIV-infected patients. Dental professionals have an important role in the early detection of the disease as these manifestations may be its first symptoms ${ }^{3,16}$.

However, due to a lack of adequate knowledge, dental surgeons are routinely influenced by fear, prejudice, confusion and ambivalence concerning the proper conduct with regard to HIV+ patients and previous experiences with AIDS patients. Their fear may stem from having lost other patients to the disease, thus denying care to or referring HIV+ patients, transgressing the ethical principles that govern the profession $^{3,15,17-18}$.

It is during graduation course that students should acquire knowledge about HIVIAIDS and other infectious diseases and make a habit of adopting biosecurity measures in order to be aware of the best course of action to take after exposure to possible pathogens $\mathbf{s}^{2,4,19}$, thereby developing an understanding that all knowledge acquired will have repercussions on their attitudes and behavior in their daily professional practice of dentistry ${ }^{4}$. Therefore, it is important to study the current situation of university students and future professionals, in order to influence subsequent students and raise awareness in current students. The main objective of this study is to assess the levels of knowledge, risk perception and attitudes in Dentistry students at Southwest Bahia State University.

\section{METHODS}

This descriptive, observational, cross-sectional study was conducted among undergraduate dental students between December 2013 and March 2014, after approval by the institution's Research Ethics Committee (REC), under protocol 451.195. The data collection tool used was a structured questionnaire with 33 objective questions, which were formulated after reflecting on other similar-themed articles. The study made use of convenience samples, comprising students from the fourth semester (second year) up to the tenth semester (final year), when students are constantly involved with patient care and the dental clinic.

The questionnaire was divided into five parts:

1. demographic factors, including gender, semester (course year) and age;

2. seven questions involving attitudes with regard to the treatment of HIV+ patients, the legal and psychological aspects involved in treating these patients and compliance in treating them. Answers were assessed using a threepoint Likert scale (agree, neutral and disagree) and given respective scores from 2 to 0 for attitudes which a professional should have, or, conversely, from 0 to 2 for negative attitudes. Values above $75 \%$, between $50 \%$ and $75 \%$, and below $50 \%$ were considered positive, indifferent/neutral and negative, respectively. The highest scores suggest attitudes that a professional should have in his/her clinical routine, the maximum value being $14(7 \mathrm{x}$ 2). Low scores may indicate intolerance and lack of theoretical/practical preparation when treating patients infected with the virus;

3. Fourteen questions regarding the epidemiology of sharps injuries and the post-accident measures to be taken;

4. Ten questions regarding students' risk perception concerning patient care, biosecurity and prevention of cross infection. Answers to each item were similarly assessed using the three-point Likert scale. Higher scores indicate that the student has good perception with regard to the risks involved when treating any patient, whether infected with HIV or not, the maximum score being 20 $(10 \times 2)$. Lower scores suggest poor perception 
regarding these aspects, increasing the risk of occupational infections;

5. Six questions about the students' views regarding the academic knowledge they have acquired on aspects such as virology, use of Personal Protection Equipament, sterilization, AIDS, among others. This part also includes a question about the main cell types affected by the AIDS virus and a further 24 questions that assess the students' knowledge of the main clinical signs exhibited by HIV+ patients, routes of infection, preventive measures, treatment and oral manifestations. Answers on the knowledge that students obtained during the course were assessed using two options for each of the 24 questions mentioned, "correct" and "incorrect". Correct answers, whether true (16 questions) or false (8 questions) received a score of 2 points, with incorrect answers scoring 0 points. A student's total score is made up of the sum of the points assigned to each answer and may therefore vary between $0 \%$ (no correct answers) and 100\% (all correct answers: $24 \times 2=48$ ). High scores suggest that students have sought and obtained knowledge about AIDS and all the aspects relating to its development. Low scores, on the other hand, reveal students with insufficient knowledge, who are insufficiently prepared to recognize and treat infected patients. Scores lower than 25\%, between $25 \%$ and $50 \%$, between $50 \%$ and $75 \%$, and higher than $75 \%$ indicate what is considered to be weak, moderate, good and excellent knowledge, respectively.

\section{RESULTS}

Of the 135 students enrolled between the fourth and tenth semesters, $100(74.07 \%)$ returned the questionnaires properly completed. The sample consisted mainly of female students $(60 \%)$ with an average age of 22.9 years.

In relation to the attitude variable (Table 1 ), the overall percentage obtained, by means of the Likert scale, was $54.3 \%$, considered negative, with differences between semesters, revealing higher scores for less advanced semesters, such as the fourth (57.1\%). Regarding the question "Should there be some kind of specialized course on theoretical and practical knowledge regarding care of HIV+ patients?", results were very low, with only $17 \%$ disagreeing with the statement.

Regarding the percentage of injuries to students, $25 \%$ reported having suffered injuries with sharps, with more occurrences in the final semesters: $36.4 \%$ in the seventh and $35.7 \%$ in the tenth, though not the ninth semester, in which no participating students reported having suffered injury. As for the causes of accidents and the subsequent measures taken, the highest respective percentages indicated improper handling of sharps (52\%) and washing the area with soap and water (92\%).

As for the students' risk perception variable (Table $2)$, the overall percentage was obtained in the same way as for the attitude variable, namely $61.7 \%$, considered negative, with differences between semesters. The highest percentages were found in the more advanced semesters, with $68.9 \%$ for the eighth and $66.4 \%$ for the tenth semester. $81 \%$ of the students agreed with the statement "I consider all patients to be potentially infectious".

With regard to the students' self-assessments about the academic knowledge they had acquired, the "use of PPE" proposal showed the highest percentage for the "adequate" option, at 96\%. In contrast, "measures to be taken after a sharps injury" showed the lowest percentage, $46 \%$. As for the question concerning the main cell types affected with the occurrence of AIDS, $64 \%$ of the students checked T-lymphocytes, however $25 \%$ of the students from the ninth semester and $21.4 \%$ from the tenth did not know the correct answer.

In relation to the variable measuring the students' knowledge about AIDS patients (Table 3), the overall percentage was obtained from the sum of correct answers, $64.1 \%$, considered good. There were differences between semesters, with higher scores found in the more advanced ones. The ninth and tenth semesters showed scores of $67.4 \%$ and $66.7 \%$, respectively, with the lowest score, $51.8 \%$, being found in the fourth semester. Regarding the clinical signs that can alert a dental surgeon as to a patient infected with HIV, the item with the lowest score was "sore throat", with 35\% in agreement. As for the routes of infection in which HIV can be isolated, the highest percentage found was for "blood" (97\%). With regard to general knowledge about HIVIAIDS, only $9 \%$ of students disagree with the statement "I must heighten caution with cross-infection control measures when treating AIDS patients". On the other hand, in relation to oral manifestations in $\mathrm{HIV}+$ patients, only $32 \%$ agreed that "an increase in the prevalence of tooth decay occurs". 


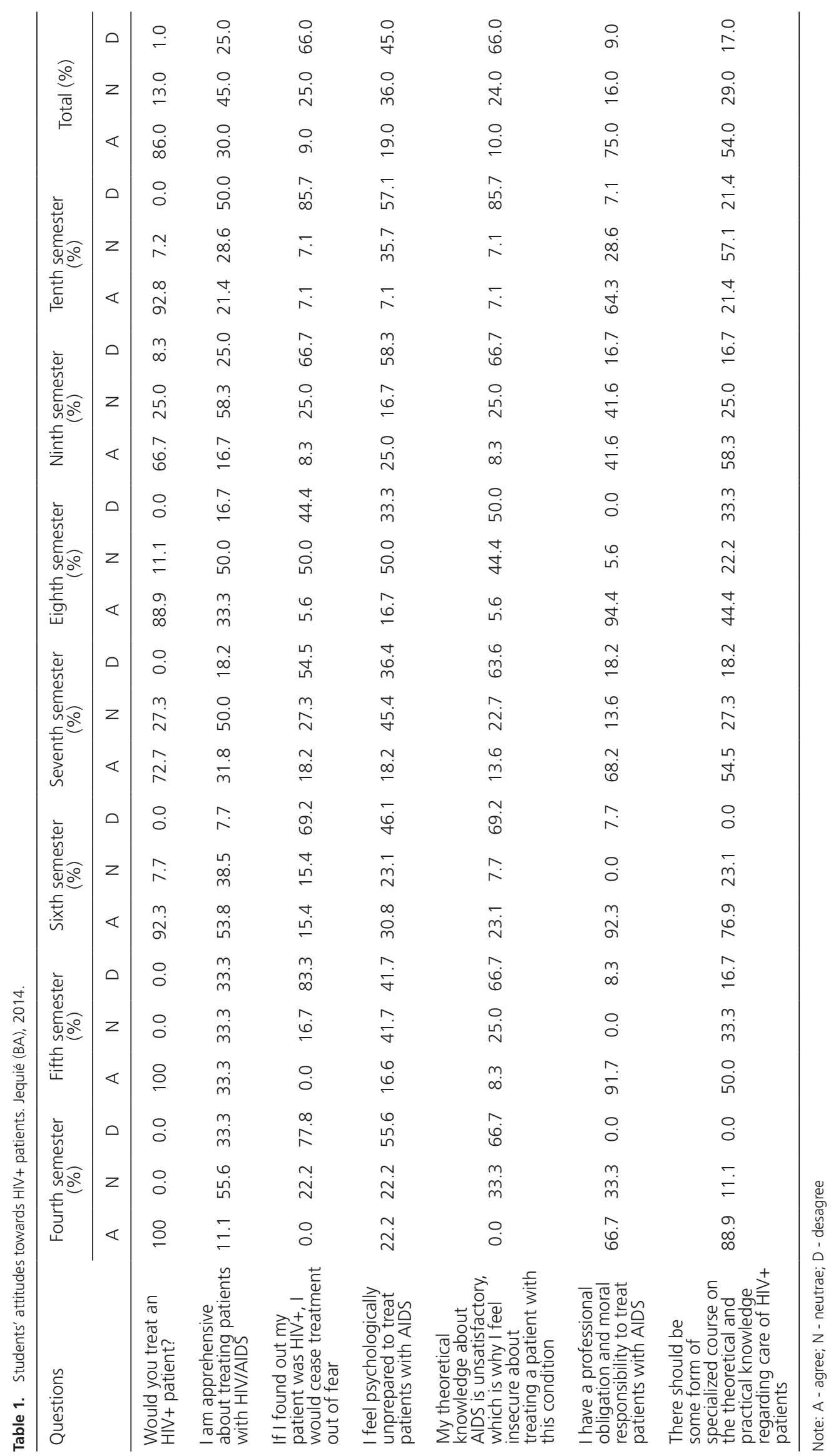




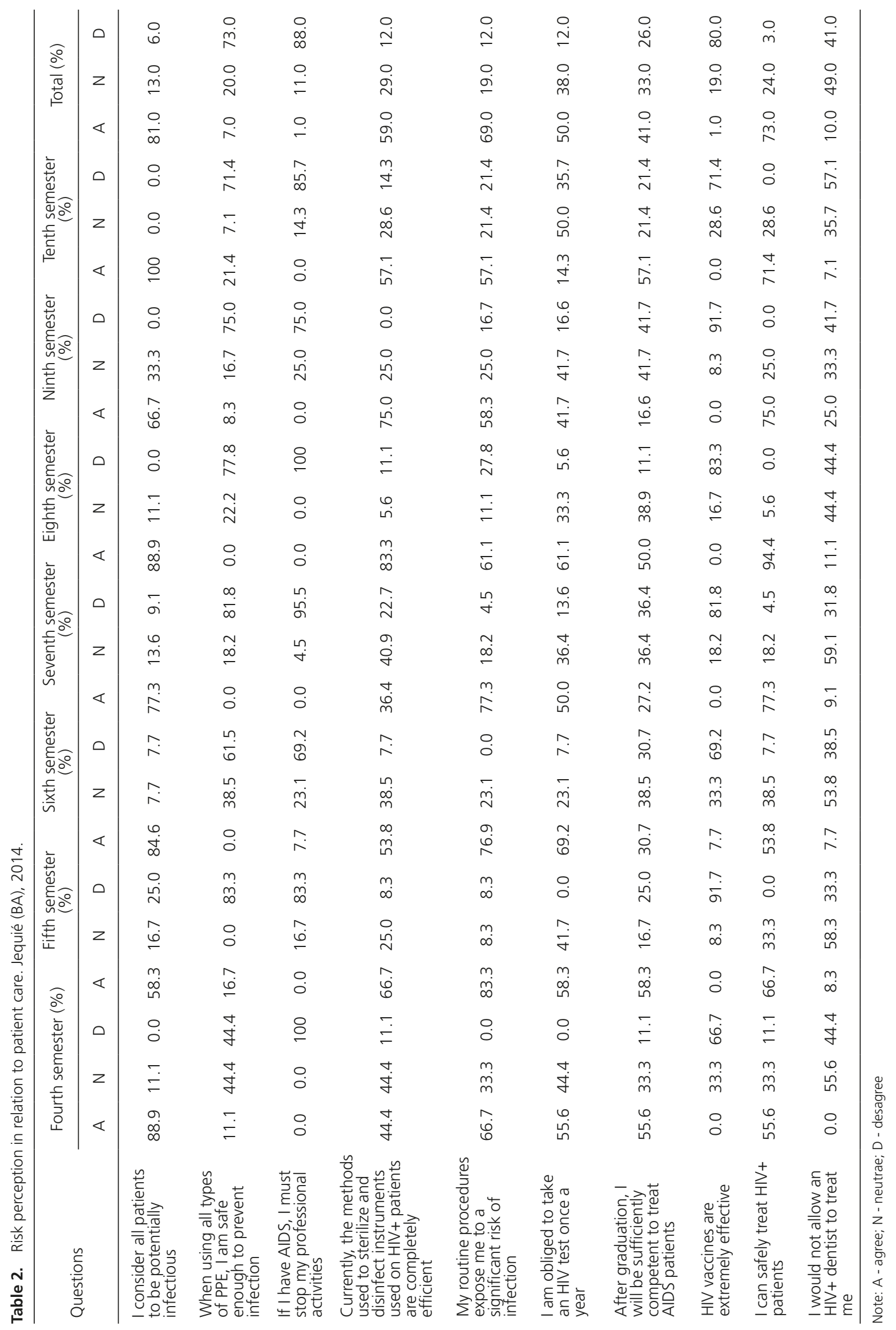


Table 3. Knowledge about patients infected with HIV. Jequié (BA), 2014.

\begin{tabular}{|c|c|c|}
\hline \multirow{2}{*}{ Clinical signs } & \multicolumn{2}{|c|}{ Total (\%) } \\
\hline & Correct & Incorrect \\
\hline Sore throat & 35.0 & 65.0 \\
\hline Increase in body mass & 85.0 & 15.0 \\
\hline Chronic fever & 62.0 & 38.0 \\
\hline Generalized lymphadenopathy & 74.0 & 26.0 \\
\hline Mucosal erythema and focal ulcerations & 78.0 & 22.0 \\
\hline Oral candidiasis, shingles and/or hairy leukoplakia & 82.0 & 18.0 \\
\hline \multirow{2}{*}{$\begin{array}{l}\text { Routes of infection } \\
\text { in which the virus can be isolated }\end{array}$} & \multicolumn{2}{|c|}{ Total (\%) } \\
\hline & Correct & Incorrect \\
\hline Saliva & 69.0 & 31.0 \\
\hline Urine & 66.0 & 34.0 \\
\hline Tears & 77.0 & 23.0 \\
\hline Blood & 97.0 & 3.0 \\
\hline Semen & 92.0 & 8.0 \\
\hline Genital secretions & 93.0 & 7.0 \\
\hline Breast milk & 80.0 & 20.0 \\
\hline Injectable drugs & 83.0 & 17.0 \\
\hline \multirow{2}{*}{ General knowledge } & \multicolumn{2}{|c|}{ Total (\%) } \\
\hline & Correct & Incorrect \\
\hline Control measures against Hepatitis B infection also provide protection against HIVIAIDS transmission. & 62.0 & 38.0 \\
\hline I must heighten caution with cross-infection measures when treating AIDS patients. & 9.0 & 91.0 \\
\hline Antiretroviral therapy completely cures an HIV+ individual. & 80.0 & 20.0 \\
\hline Can I treat HIV/AIDS with antiviral drugs? & 61.0 & 39.0 \\
\hline HIV carriers must be treated in specialized service. & 37.0 & 63.0 \\
\hline \multirow{2}{*}{ Oral manifestations } & \multicolumn{2}{|c|}{ Total (\%) } \\
\hline & Correct & Incorrect \\
\hline Oral candidiasis and hairy leukoplakia are bad prognostic markers. & 57.0 & 43.0 \\
\hline Angular cheilitis is a form of manifestation of Candida infection. & 44.0 & 56.0 \\
\hline Linear gingival erythema is a distinctive periodontal manifestation of the disease. & 35.0 & 65.0 \\
\hline An increase in the prevalence of tooth decay occurs. & 32.0 & 68.0 \\
\hline Kaposi's sarcoma is one of the neoplasms strongly associated with the disease. & 49.0 & 51.0 \\
\hline
\end{tabular}

\section{DISCUSSION}

The knowledge a student acquires in his/her academic field can make him/her a professional who is conscious of his/her attitudes and who has greater awareness of the risks involved within the workplace. During the graduation course, teachers should encourage them to seek the most up-to-date knowledge possible on the infectious diseases to which a dental surgeon may be exposed. Furthermore, students should be psychologically prepared for treating people with infectious diseases and be stimulated to seek self confidence in any kind of treatment, treating all patients with respect.
As far as the findings related to the attitude variable are concerned, students showed negative attitudes. Other studies demonstrated the same results for both working professionals and students, who demonstrate fear and negative tendencies toward HIV+ patients, as well as

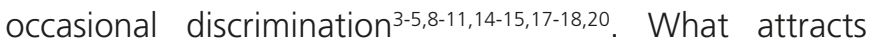
particular attention in the findings of this study is the fact that students in semesters that have had little contact with the dental clinic, showed less apprehensive or fearful attitudes regarding the treatment of infected patients compared to students in more advanced semesters, of whom greater psychological preparation would be expected due to their greater practical experience. This 
same fact is reported in some studies ${ }^{4,17}$ but differs from others ${ }^{18}$. The majority would treat patients infected with AIDS, however almost all of the students agreed that there should be some kind of specialized course on theoretical and practical knowledge regarding care of HIV+ patients. It is the responsibility of the university to transmit this kind of knowledge during routine clinical procedures, without requiring a separate course to this end.

Also, $25 \%$ of students reported suffering sharps injuries, the majority of them belonging to more advanced semesters, which is to be expected due to the higher number of practices. However, it would be unexpected based on the degree of preparedness of these students, as the major reasons for these accidents were the improper handling of instruments, the washing of materials in incorrect attire and haste in performing the treatment. This was also shown in the research conducted by Lima et al. ${ }^{2}$, the only difference being the percentage of occupational accidents affecting dental students (59.5\%). Likewise, other studies showed higher percentages ${ }^{9,15,21}$, however yet others showed results inferior to those of the present study ${ }^{8,13}$, with sharps injuries being the biggest culprits in occupational accidents in dentistry. As for post-accident measures, it may be inferred from this study that students have not been properly instructed or do not seek to apply the knowledge they have acquired, as only $12 \%$ filled in the biological accident notification forms and only $16 \%$ asked for the source-patient's serology. Other studies in the literature also revealed poor adherence to postexposure protocols and unsatisfactory knowledge in this regard ${ }^{2,9,10,21-22}$.

As for the risk perception variable, students also maintained a negative position. However, the more advanced semesters, as might be presumed, showed better risk perception than those less advanced, as students in the latter stages are just beginning to form their perceptions of risk. The same result has been described in other studies $2,9-11,14-15,21-22$. In contrast, research performed by Jafari et al..$^{23}$ demonstrated that students in the final years of an Iranian university's dentistry course showed good risk perception regarding the prevention and transmission of HIV due to their constant contact with sick patients, since these students helped out in a care center for patients with diseases. These findings in Iran show the important need for continued education throughout a student's clinical training, thus preparing then to practice the profession.

The students' self-assessments regarding the academic knowledge they had acquired suggest that the majority believe they possess adequate knowledge concerning cross infections and the use of PPE. However, a large portion of the sample opted for heightened caution when treating HIV+ patients, which was contradictory, as the majority of students answered that they consider all patients to be potentially infectious. As for the use of PPE, the majority of students reported having suffered injuries when washing instruments due to their being incorrectly attired. Students assessed themselves negatively as to knowledge of virology, aspects related to HIV/AIDS and measures to be taken after sharps injuries.

A correlation was found between what they thought about the academic knowledge they had acquired in respect of these three items and what they chose as correct in the survey questions. Many students revealed that they did not know the main cell type affected by HIV, that sore throat associated with other factors is a clinical sign of possible infection, that urine and saliva are not usual routes of infection in which the virus can be isolated and that an increase in the prevalence of tooth decay does indeed occur. Analyzing all the variations of the knowledge variable, most students demonstrated having a good knowledge of the aspects that involve HIV/AIDS, as observed in other studies ${ }^{5,19-20}$. The more advanced semesters scored better, corroborating the findings of Brailo et al. ${ }^{18}$, in which, although general knowledge in all semesters was considered low, there was more progression in the final semesters. In the present study, this fact can be considered a positive factor, since a progression in the acquisition of knowledge over the semesters was found, even though the results, albeit considered good, were considered insufficient in preparing a professional for his/her work routine.

With regard to the relationship between knowledge and attitudes, studies similar to the present one can be found in which, although students exhibit a level of knowledge considered to be good, their attitudes and perceptions of risk do not bear this out, suggesting flaws in the relationship between theory and practice ${ }^{5,20}$. On the other hand, several studies report knowledge of HIVIAIDS by students and dental surgeons as being unsatisfactory or poor $3,9-12,15,18,22-24$.

We propose further research, in other institutions, on the same topics as the present study, in order to assess the knowledge acquired by students and whether it is enough to provide an awareness that can generate attitudes of ethical and legal responsibility, as well as improvements in the academic curriculum, which may include approaches involving precautionary standards, cross infections and 
doctor-patient relationships in all matters associated with the clinic, demanding from students greater interrelation between theory and practice.

\section{CONCLUSION}

It may be concluded, with the completion of this study, that students do not harbour positive attitudes toward the care of patients with HIV/AIDS, which reveals a potential lack of preparation in the relationships between doctors and HIV+ patients. Risk perception is poor, which may possibly lead to a higher rate of sharps injuries, and students' knowledge on aspects involving HIV/AIDS is insufficient throughout the course. Thus, we propose that higher education institutions take the initiative to train professionals to be more aware of their ethical and legal responsibilities and obtain greater

\section{REFERENCES}

1. Berkenblit GV, Sosman JM, Bass M, Gebrekristos HT, Cofrancesco Junior J, Sullivan LE, et al. Factors affecting clinician educator encouragement of routine hiv testing among trainees. J Gen Intern Med. 2012;27(7):839-44. doi: 10.1007/s11606-012-1985-9.

2. Lima AA, Azevedo AC, Fonseca AGL, Silva JLM, Padilha WWN Acidentes ocupacionais: conhecimento, atitudes e experiências de estudantes de Odontologia da Universidade Federal da Paraíba. Pesq Bras Odontoped Clin Integr. 2008;8(3):327-32.

3. Corrêa EMC, Bittar TO, Meneghim MC, Ambrosano GMB, Pereira AC. Nível de conhecimento e atitudes em relação a HIV/ AIDS dos cirurgiões-dentistas da cidade de Piracicaba - SP, Brasil. Rev Odontol UNESP. 2009;38(6):329-34

4. Azodo CC, Ehigiator O, Oboro $\mathrm{HO}$, Ehizeli AO, Umoh A, Ezeja $E B$, et al. Nigerian dental students' willingness to treat HIVpositive patients. J Dent Educ. 2010;74(4):446-52.

5. Sadeghi M, Hakimi H. Iranian dental students' knowledge of and attitudes towards HIVIAIDS patients. J Dent Educ. 2009;73(6):740-5.

6. Joint United Nations. Programme on HIVIAIDS (UNAIDS). Global report: UNAIDS report on the global AIDS epidemic 2013; 2013.

7. Brasil. Ministério da Saúde. Secretaria de Vigilância em Saúde. Departamento de DST, Aids e Hepatites Virais. Boletim Epidemiológico: Aids e DST. Brasília: Ministério da Saúde; 2013 [citado 2014 Fev 10]. Disponível em: <http://www.aids. gov.br/sites/default/files/anexos/publicacao/2013/55559/_p_ boletim_2013_internet_pdf_p_51315.pdf>.

8. Murofuse NT, Alves DCI, Fávero GC, Brotto AO. Comportamento dos acadêmicos, docentes e técnicos administrativos da clínica odontológica da Unioeste: riscos ocupacionais e atividades desenvolvidas. Acta Sci. Health Sci. 2008:30(1):81-7. doi: 10.4025/actascihealthsci.v30i1.587 practical knowledge concerning infection control and post-exposure prevention.

\section{Acknowledgements}

The authors would like to thank the financial support of the Bahia State Research Support Foundation (FAPESB; Scientific Initiation scholarship \#1744/2013).

\section{Collaborators}

VCS MAGALHÃES participated in study design, data collection, analysis and writing of the manuscript. DL OLIVEIRA participated in the conception of the study design and writing the manuscript. FO PRADO was responsible for supervision and coordination of concept and study design, data collection and analysis, writing and editing of the paper.

9. Bragança DPP, Fernandes MM, Sassi C, Francesquini Júnior L, Daruge Júnior E. Condutas do cirurgião-dentista frente a acidentes biológicos. Odonto. 2010;18(35):37-44.

10. Martins AMEBL, Pereira RD, Ferreira RC. Adesão a protocolo pósexposição ocupacional de acidentes entre cirurgiões dentistas. Rev Saúde Pública. 2009;44(3):528-40. doi: 10.1590/S003489102010005000018

11. Vasconcelos MMVB, Brasi CMV, Mota CCBO, Carvalho NR. Avaliação das normas de biossegurança nas clínicas odontológicas da UFPE. Odontol Clín-Científ. 2009;8(2):151-6.

12. Garcia AFG, Rocha ES, Sousa RV, Martins VM, Massoni ACLT, Paiva SM. Knowledge of occupational diseases and immunization among healthcare students. Rev Odonto Cienc. 2011;26(3):215-21.

13. Silva JA, Paula VS, Almeida AJ, Villar LM. Investigação de acidentes biológicos entre Profissionais de saúde. Esc Anna Nery Rev Enferm. 2009;13(3):508-16.

14. Pinelli C, Garcia PPNS, Campos JADB, Dotta EAV, Rabello AP. Biossegurança e Odontologia: crenças e atitudes de graduandos sobre o controle da infecção cruzada. Saúde Soc. 2011:20(2):448-61. doi: 10.1590/S0104-12902011000200016

15. Garbin CAS, Martins RJ, Garbin AJl, Hidalgo LRC. Conductas de estudiantes del área de la salud frente a la exposición ocupacional a material biológico. Ciencia \& Trabajo. 2009;11(31):18-21.

16. Motta WKS, Nóbrega DRM, Santos MGC, Gomes DQC, Godoy GP, Pereira JV. Aspectos demográficos e manifestações clínicas bucais de pacientes soropositivos para o HIV/Aids. Rev Odontol UNESP. 2014;43(1):61-7. doi: 10.1111/j.17544505.2010.00161.x

17. Kuthy RA, McQuistan MR, Heller KE, Riniker-Pins KJ, Qian F. Dental students' perceived comfort and future willingness to treat underserved populations: surveys prior to and immediately after extramural experiences. Spec Care Dentist. 2010;30(6):2429. doi: 10.1111/j.1754-4505.2010.00161.x 
18. Brailo V, Pelivan I, Sharicic J, Vuletic M, Dulcic N, Cerjan-Letica G. Treating Patients with HIV and Hepatitis B and C Infections: Croatian Dental Students' Knowledge, Attitudes, and Risk Perceptions. J Dent Educ. 2011;75(8):1115-26.

19. Ryalat ST, Sawair FA, Shayyab MH, Amin WM. The knowledge and attitude about HIV/AIDS among Jordanian dental students: (Clinical versus pre clinical students) at the University of Jordan. BMC Research Notes. 2011;4:191. doi: 10.1186/1756-0500-4-191

20. Fotedar S, Sharma KR, Sogi GM, Fotedar V, Chauhan A Knowledge and attitudes about HIVIAIDS of students in H.P. Government Dental College and Hospital, Shimla, India. J Dent Educ. 2013;77(9):1218-24.

21. Mungure EK, Gakonyo JM, Mamdani Z, Butt F. Awareness and experience of needle stick injuries among dental students at the University of Nairobi, Dental Hospital. East Afr Med J. 2010;87(5):211-4.
22. Guruprasad Y, Chauhan DS. Knowledge, attitude and practice regarding risk of HIV infection through accidental needlestick injuries among dental students of Raichur, India. Natl J Maxillofac Surg. 2011;2(2):152-5. doi: 10.4103/0975-5950.94470

23. Jafari A, Yazdani R, Khami MR, Mohammadi M, Hajiabdolbaghi M. Effect of an Educational Course at an Iranian Dental School on Students' Knowledge of and Attitudes About HIV/AIDS. J Dent Educ. 2012;76(6):792-9.

24. Nasir EF, Åstrøm AN, David J, Wahab Ali R. HIV and AIDS related knowledge, sources of information, and reported need for further education among dental students in Sudan- a cross sectional study. BMC Public Health. 2008;8:286-94. doi: 10.1186/1471-2458-8-286

Received on: 1/2/2015

Final version resubmitted on: 27/4/2015

Approved on: 20/5/2015 
